\title{
Pengembangan Kompetensi Akuntansi dan Perpajakan Siswa SMK Mitra Bakti Husada - Bekasi
}

\author{
Widiyanti Rahayu Budi Astuti ${ }^{1}$, Dewi Gunherani ${ }^{2}$, Muliyani $^{3}$, Sri Agustini ${ }^{4}$, Fithrah Kamaliyah ${ }^{5}$ \\ Prodi Akuntansi S1, Fakultas Ekonomi, Universitas Pamulang \\ Korespondensi Penulis: dosen01397@unpam.ac.id
}

\begin{abstract}
Abstrak
Profesi kompetensi sebagai Asisten apoteker sangat perlu dilengkapi dengan pengetahuan akuntansi dan pajak. Memasuki dunia usaha mau tidak mau agar bisa sukses harus dilakukan secara professional yaitu dilengkapi dengan kecakapan mengelola keuangan dan pajak, sehingga dalam mengelola keuangan para peserta didik perlu dibekali dengan pengetahuaan tersebut. Program pelatihan yang akan diberikan yaitu akuntansi dan pajak. Program tersebut dipilih karena dianggap penting dan diharapkan dapat memberikan edukasi kepada para siswa dan siswi tersebut. Materi akuntansi dan pajak merupakan materi yang penting sebagai bekal mereka untuk meningkatkan kemampuan untuk berwiraswasta. Dengan menguasai akuntansi dan pajak diharapkan mereka dapat mengelola usaha dengan menyusun laporan keuangan akuntansi dan pajak (fiskal) sesuai standar yang berlaku.
\end{abstract}

Kata-kata kunci: Kompetensi, Akuntansi, Perpajakan

\begin{tabular}{l} 
Abstract \\
\hline Professional competence as a pharmacist assistant really needs to be equipped with \\
accounting and tax knowledge. Entering the business world, inevitably, in order to be \\
successful, it must be done professionally, namely equipped with the skills to manage \\
finances and taxes, so that in managing finances, students need to be equipped with this \\
knowledge. The training programs that will be provided are accounting and tax. The \\
program was chosen because it was considered important and was expected to provide \\
education to these students. Accounting and tax materials are important materials as a \\
provision for them to increase their ability to become entrepreneurs. By mastering \\
accounting and taxes, it is expected that they can manage their business by compiling \\
accounting and tax (fiscal) financial reports according to applicable standards.
\end{tabular}

Keywords: Competence, Accounting, Taxation 


\section{PENDAHULUAN}

Sekolah Menengah Kejuruan (SMK) Mitra Bakti Husada di Bekasi untuk jurusan Farmasi, selepas dari SMK mereka diharapkan akan menjadi asisten apoteker yaitu suatu profesi di bidang Kesehatan yang sangat dekat dengan dunia usaha. Demikian dekatnya lulusan SMK Mitra Bakti Husada - Bekasi jurusan Farmasi dengan dunia usaha, karena memang dimaksudkan sebagai tenaga siap pakai yang bergelut untuk memberikan pelayanan farmasi yang sangat dibutuhkan rumah sakit maupun apotik untuk pelayanan medis kepada masyarakat atau dapat juga sebagai tenaga kerja siap pakai diperusahaan obat maupun farmasi yang melayani masyarakat. Profesi kompetensi sebagai Asisten apoteker sangat perlu di lengkapi dengan pengetahuan akuntansi dan pajak. Memasuki dunia usaha mau tidak mau agar bisa sukses harus dilakukan secara professional yaitu dilengkapi dengan kecakapan mengelola keuangan dan pajak, sehingga dalam mengelola keuangan para peserta didik perlu dibekali dengan pengetahuan tersebut.

Program pelatihan yang akan diberikan yaitu akuntansi dan perpajakan. Program tersebut dipilih karena dianggap penting dan diharapkan dapat memberikan edukasi kepada siswa-siswi tersebut. Pelatihan-pelatihan itu meliputi Perkenalan Akuntansi seperti pembuatan Jurnal-jurnal dan pembukuan lainnya, serta pelatihan perpajakan meliputi perkenalan dengan subjek, non subjek, objek dan non objek pajak. Penyelenggaraan pengabdian kepada masyarakat ini diselenggarakan oleh Program Studi Akuntansi Universitas Pamulang yang bekerjasama dengan dosen dan mahasiswa di Lingkungan Fakultas Ekonomi Prodi Akuntansi serta didukung Oleh LPPM Universitas Pamulang yang menyusun dan mengembangkan program-program sesuai dengan kebutuhan di SMK Mitra Bakti Husada - Bekasi. Semoga saja, dengan adanya berbagai perangkat keahlian dan bidang keilmuan yang dimiliki oleh Universitas Pamulang diharapkan menjadi modal besar untuk berperan dalam melakukan berbagai kegiatan nyata sebagai pengamalan ilmu yang dimiliki oleh dosen guna memenuhi kebutuhan masyarakat dengan selalu menjunjung tinggi profesionalisme, integritas, dan transparansi serta diharapkan dapat dirasakan oleh masyarakat sehingga tingkat kualitas kehidupan dan kesejahteraan masyarakatnya dapat meningkat ke arah yang lebih baik.

Pengabdian kepada masyarakat bertujuan untuk membantu masyarakat dalam proses pemberdayaan/pengembangan diri dalam rangka mencapai perikehidupan yang lebih maju, adil, dan sejahtera. Termasuk di dalamnya adalah usaha untuk meningkatkan kemampuan masyarakat dalam memecahkan berbagai persoalan yang dihadapi. Oleh karena 
itu, pengabdian kepada masyarakat haruslah diarahkan kepada kegiatan-kegiatan yang dampak dan manfaatnya dapat dirasakan secara nyata oleh masyarakat. Titik pijak pengabdian kepada masyarakat adalah kebutuhan dan perkembangan masyarakat itu sendiri. Persoalan-persoalan yang dihadapi masyarakat yang segera membutuhkan solusi (penyelesaian) ataupun potensi potensi yang dimiliki yang bisa dikembangkan, perlu dikenali terlebih dulu. Upaya ini dapat dilakukan dengan suatu penelitian atau pengkajian ulang terhadap hal-hal yang ditemui pada saat menerapkan, mengembangkan, dan menyebarluaskan ilmu pengetahuan. Keberpijakan pada kebutuhan dan perkembangan masyarakat amat penting untuk diperhatikan dalam pelaksanaan pengabdian kepada masyarakat. Perlu diingat bahwa pengabdian kepada masyarakat antara lain bertujuan untuk meningkatkan kualitas sumber daya manusia agar dirinya mampu menghadapi dan menjalani perubahanperubahan menuju perbaikan dan kemajuan hidup sesuai dengan nilai-nilai sosial dan kultural yang dihidupi. PKM ini diharapkan dapat memberikan sumbangan positif kepada siswa dan siswi dalam rangka meningkatkan pendidikan mereka sehingga mereka bisa merasa punya hak yang sama dengan orang pada umumnya yang belajar di bangku pendidikan formal.

\section{METODE}

Pelaksanaan pengabdian ini dilakukan dengan tiga tahap, dimana tahapan pertama merupakan tahap persiapan. Pada tahap ini kelompok pengabdian melakukan survey pendahuluan untuk melihat kondisi di lapangan dan menentukan siapa saja para siswa dan siswi yang berada di SMK Mitra Bakti Husada Bekasi yang akan hadir. Dalam tahap ini, penentuan para siswa dan siswi yang diundang berdasarkan dari kompetensi yang sesuai dengan materi yang diberikan yakni pengantar akuntansi dan pajak. Sasaran dan permasalahan yang dihadapi oleh para siswa dalam kehidupan masyarakat dari aspek hukum. Tahap selanjutnya merupakan tahap pelaksanaan kegiatan pengabdian, dimana dalam tahap ini tim PKM melakukan kegiatan memberikan pemahaman tentang pengertian akuntansi dan pajak serta pentingnya arti akuntansi dan pajak bagi para siswa dalam menjalani kehidupan di masa mendatang. Kegiatan dilakukan dengan menggunakan metode ceramah, diskusi, dan latihan. Adapun langkah-langkah dalam pelaksanaan kegiatan pengabdian ini adalah sebagai berikut:

Langkah 1: Peserta pelatihan diberikan materi mengenai pengantar akuntansi dan pajak yang berkaitan dengan pemahaman tentang akuntansi secara umum, arti pentingnya pajak bagi para siswa dan siswi.

Langkah 2: Peserta diberikan kesempatan untuk mendiskusikan materi yang telah diberikan. 
Kesempatan tanya jawab diberikan untuk memperjelas keraguan serta ketidaktahuan peserta tentang materi yang disampaikan.

Langkah 3: Peserta berlatih untuk menyusun pengantar akuntansi dan pajak dari soal kasus yang diberikan.

\section{HASIL DAN PEMBAHASAN}

Hasil pelaksanaan PKM yang dilakukan pada tanggal 27 sampai dengan 28 Oktober 2020 dengan jumlah peserta sebanyak 50 orang, hal tersebut menunjukkan bahwa :

1. Memberikan pendidikan dan pencerahan kepada siswa dan siswi mengenai dasardasar dalam akuntansi mengenai pembukuan yang baik dan pajak mengenai pengantar pajak tentang subjek, non subjek, objek, non objek pajak;

2. Siswa/siswi yang mengikuti pelaksanaan Pengabadian Kepada Masyarakat mengenai pembelajaran akuntansi dan pajak ini, mereka lebih mengerti dan lebih paham mengenai pembukuan dalam akuntansi serta pengenalan pajak;

3. Siswa/siswi antusias memperoleh informasi terbaru mengenai perkembangan ilmu akuntansi dan pajak dalam dunia perkonomian dan bisnis. Antusias tersebut terlihat ketika para siswa dan siswi kami berikan soal-soal yang dikerjakan dengan baik dan penuh antusias, dimana santri/satriawati mengerjakan dengan baik dan benar;

4. Dampak yang positif dan adanya PKM ini bahwa siswa dan siswi tidak hanya fokus dengan pelajaran mengenai bidang farmasi saja namun mereka juga dapat mengembangkan ilmu akuntansi mereka yang seharusnya diperoleh di bangku pendidikan formal.

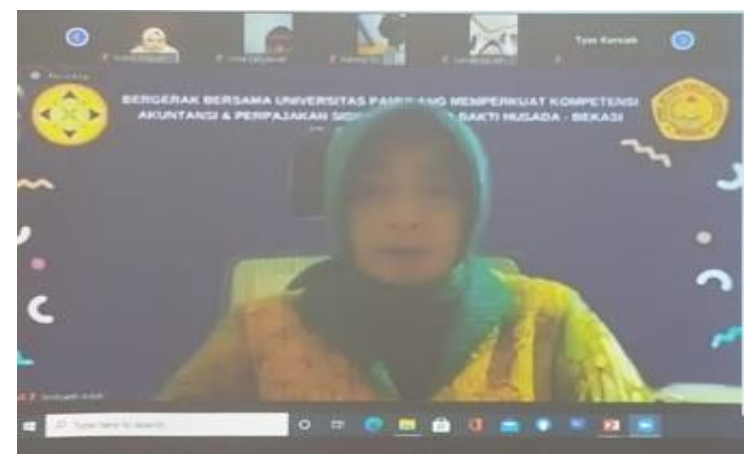

Gambar 1. Sambutan ketua PKM: Widiyanti Rahayu B.A., S.H., M.H

Melaksanakan pengabdian kepada masyarakat merupakan kewajiban civitas academica Perguruan Tinggi. Selain kompetensi akademik dan komitmen sosial, kegiatan ini butuh kesamaan langkah, kesepahaman, kerjasama, dan koordinasi diantara para pihak. Hasil pelaksanaan kegiatan PKM yaitu berupa memperkenalkan pendidikan dan pendampingan kepada siswa dan siswi di SMK Mitra Bakti Husada - Bekasi telah dilaksanakan dengan baik. PKM ini diikuti Peserta dari SMK Mitra Bakti Husada Bekasi sebanyak 39 orang siswa dan siswi kelas 12 jurusan farmasi dengan 2 orang wali kelas, 1 kaprodi Farmasi, kepala Sekolah dan Ketua 
Yay dan 3 orang Tim Tehnis IT dengan 5 orang Dosen dan 4 orang Mahasiswa Fakultas Ekonomi Prodi Akutansi Universitas Pamulang. Dan mudahmudahan kegiatan PKM ini memberikan manfaat kepada semua pihak yang terlibat dalam pengabdian kepada masyarakat ini.

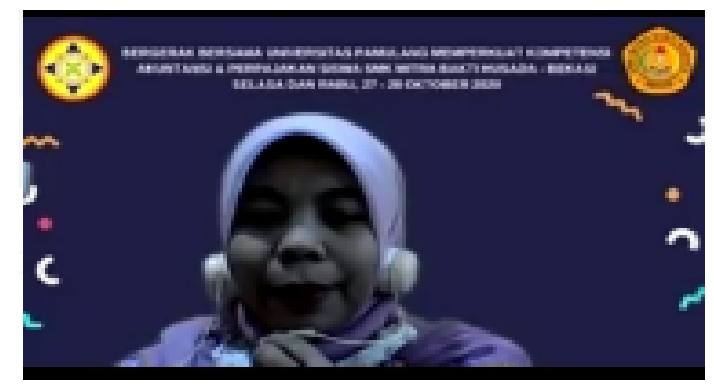

Gambar 2. Penyampaian materi akuntansi oleh narasumber: Muliyani, S.Pd., M.M.

Dampak yang positif dan adanya PKM ini bahwa siswa dan siswi yang mengikuti PKM ini adalah kelas 12 jurusan Farmasi tidak hanya fokus dengan pelajaran mengenai bidang farmasi yang nantinya setelah lulus akan sangat dekat dengan dunia usaha, yang tentunya sangat memerlukan pengetahuan ilmu akuntansi dan pajak yang tidak diperoleh dari kurukulum sekolah, sehingga bagi siswa dan siswi pengetahuan ini sebagai pengetahuan tambahan untuk bekal lulus dari SMK tersebut. Dengan semua itu agar siswa dan siswi mampu bersaing di dunia modern saat ini, dan bisa bersosialisasi dalam kehidupan di masyarakat terutama di dunia kerja nantinya.

\section{KESIMPULAN}

Titik pijak pengabdian kepada masyarakat adalah kebutuhan dan perkembangan masyarakat itu sendiri. Keberpijakan pada kebutuhan dan perkembangan masyarakat amat penting untuk diperhatikan dalam pelaksanaan pengabdian kepada masyarakat. Perlu diingat bahwa pengabdian kepada masyarakat antara lain bertujuan untuk meningkatkan kualitas sumber daya manusia agar dirinya mampu menghadapi dan menjalani perubahan-perubahan menuju perbaikan dan kemajuan hidup sesuai dengan nilai-nilai sosial dan kultural yang dihidupi. Sehubungan dengan hal tersebut terkait dengan Mitra yaitu SMK Mitra Bakti Husada - Bekasi yang diterapkan dan di kembangkan di SMK Mitra Bakti Husada Bekasi yang dikembangkan meliputi jurusan farmasi untuk menjadi Asisten Apoteker, jurusan Perawan untuk menjadi Asisten Perawat dan jurusan Tata Boga. Hal ini diambil sebagai perwujudan untuk mencetak generasi yang berkualitas dan berwawasan. Keberadaan SMK Mitra Bakti Husada Bekasi yang secara intensif mampu memberikan resonansi dalam mewujudkan lembaga pendidikan memberikan sumbangan besar pada hajat besar bangsa ini melalui alumninya dalam mengisi pembangunan manusia seutuhnya.

Pelaksanaan kegiatan PKM ini diharapkan tetap dilakukan secara rutin untuk membantu siswa dan siswi dalam 
memperkenalkan pendidikan dan dapat menambahkan jumlah tenaga memberikan pelatihan akuntansi dan pendamping/tutor supaya ada penambahan pajak kepada siswa dan siswi SMK tersebut. Selain itu diharapkan dapat memberikan pengetahuan mengenai akuntansi dan pajak sebagai bekal mereka di masa depan dan mampu bersaing. Dalam pelaksanaan PKM selanjutnya diharapkan agar mampu menjalin kerjasama dengan pihak-pihak terkait agar bisa mendukung kegiatan yang ada,

\section{REFERENSI}

Aminah. (2014). Penerapan Diskusi Kelompok pada Mata Pelajaran Perpajakan untuk Meminimalkan Kesalahan Siswa. Jurnal Pendidikan Ilmu Sosial. 24(2): 93-108.

Arifin, Zainal. (2012). Implementasi Manajemen Stratejik Berbasis Kemitraan dalam Meningkatkan Mutu SMK. Jurnal Universitas Pendidikan Indonesia. XIV(1): 1-5.

Chasanah, Laela Meni' Nur. (2014). Pengaruh Motivasi Belajar Perpajakan, Keaktifan Peserta Didik, Disiplin Belajar, dan Intensitas Mengerjakan Soal Latihan Perpajakan terhadap Prestasi Belajar Perpajakan Peserta Didik. Economic Education Analysis Journal, 3(2): 1-5.

Dhofier, Zamakhsari. (2011). Tradisi Pesantren Studi tentang Pandangan Hidup Kiai dan Visinya Mengenai Masa Depan Indonesia, cet. ke-9, LP3ES, Jakarta.

Mardiasmo. (2006). Perpajakan. Yogyakarta. Andi.

Nafisah, K., Margunani, M., \& Latifah, L.

(2015). Faktor-faktor yang Mempengaruhi Hasil Belajar Siswa Akuntansi. Economic Education Analysis Journal, 4(1).

Nashiroh, Marfuatun dan Sukirno. (2020). Peningkatan Aktifitas dan Hasil Belajar Akuntansi melalui Implementasi Model Pembelajaran Kooperatif Teams Games Tournament. Jurnal Pendidikan Akuntansi Indonesia. 18(1): 20-35.

Perwita, Dyah. (2017). Upaya Guru Sekolah Menengah Kejuruan (SMK) dalam Meningkatkan Minat Berwirausaha Siswa. Jurnal Pendidikan Ekonomi UM Metro. 5(2): 9-14.

Poerwadarminta, WJS. (2003). Kamus Umum Bahasa Indonesia. Jakarta. Balai Pustaka.

Setyawan, Cornelius Hery. (2012). Peningkatan Hasil Belajar Perpajakan melalui Media Taxi Snaders pada Siswa. Jurnal Pendidikan Ekonomi Dinamika Pendidikan. VII(1): 53-66.

Sodikin, Sodikin Slamet Sugiri dan Riyono, Bogat Agus. (2019). Akuntansi Pengantar 1, Edisi Kesembilan. 